\title{
Office Views and Productivity - Case Study of Offices at Chandigarh
}

\section{Gurkirpal Singh}

\begin{abstract}
Major spending of companies is on staff salaries. In order to be efficient, progressive, profitable and competitive in the profession, the staff should be productive. Staff is productive when Office Environment is comfortable with regard to work conditions. In this paper effect of Views from Offices on productivity of occupants is highlighted. A research to this regard was conducted in Offices of city of Chandigarh(India) capital of Punjab and Haryana state. Various Offices were sampled and Questionnaire survey of productivity was conducted to get first hand information from Office Occupants.
\end{abstract}

Keywords: productivity, office design, views

\section{Introduction}

People spend most of the time indoors -- at office or home. The profitability of any organization is dependent on the productivity(efficiency) of the employees. The productivity of the employees is dependent on comfort levels at their office. World over research has been done to study the effect on office views on productivity but no research done in India. so the study is conducted to identify the effects of views in offices at Chandigarh (India).

Aim is to study the effect of views on productivity of office employees.

\section{Literature review}

Different literature refer to the study of various offices and office buildings indicated that the factors such as dissatisfaction, cluttered workplaces and the physical environment are playing a major role in the loss of employees' efficiency(productivity).

How workspace is designed and occupied affects not only how people feel, but also their work performance, their commitment to their employer, and the creation of new knowledge (human capital) in the organization. These are the cornerstones of the domain known as the environmental psychology of workspace. Moreover, measures of user perceptions of environmental conditions can be used to diagnose building performance and the effectiveness of building systems (Vischer \& Fischer, 2005).A large number of work environment studies have tested users' satisfaction in reference to specific workspace features(Dodo et al 2012, Aries et al 2012, Ozdemir 2010, Park 2006, Oaks 2003 ,Ulrich 2002). These studies show that people's preferences are affected by, among other things, views.

Sample

\section{Methodology}

660 employees from various offices of Chandigarh were surveyed as sample. The age range of the sample was between 25-60 years. The minimum educational qualification was graduation. For inclusion in the study the employee must be working in that particular organization since last three years. Primary data was collected through a structured questionnaire. The questionnaire was developed on the basis of the research literature review. The questionnaire consisted of 5 questions on views variable to be rated on a five point Likert scale.

\section{Data Analysis}

Statistical techniques of correlation has been used for result findings and in-depth analysis of the different components of office environment on the performance level of the employees. As research tool for data analysis SPSS software is used for this research.

\section{Results}

Table 1: Descriptive Statistic of Views component of Office Design

\begin{tabular}{|l|l|l|l|}
\hline Factors & Respondents (N) & Mean & Std. Deviation \\
\hline Views & 660 & 2.8852 & .81757 \\
\hline
\end{tabular}


Office Views And Productivity - Study Of Offices At Chandigarh

Table 2: Correlation between Elements of Office Design and Employee Productivity

\begin{tabular}{|l|l|l|}
\hline Office Design Element & Pearson Correlation (r) & Significance \\
\hline Views & $.163^{* *}$ & .00 \\
\hline
\end{tabular}

**Correlation is significant at the 0.01 level (2-tailed)

\section{Result analysis}

Relationship between office design and productivity was determined by using the Pearson's Correlation. It shows that when the Views of the office is not comfortable employees productivity is affected. The positive relationship between Views and productivity $(r=0.163)$ at 0.00 shows that employees' productivity correlates to Quality of Views in the offices.(Table 2).

\section{Discussion}

Collected data Analysis revealed that office design has a substantial impact on the employees' productivity. The overall impact of different elements showed that Views affects the productivity of most employees. The results are similar to previous research viz; Dodo et al 2012, Aries et al 2012, Ozdemir 2010, Park 2006, Oaks 2003 ,Ulrich 2002.

Present research survey found correlation between employee's efficiency(productivity) and Views. Tapping Views from indoors as a resource reduces energy use and improves productivity.

Limitations the research survey is limited to Views conditions only and is not exhaustive. The sample size was not diverse enough to give the image of all organizations functioning in India.

\section{Future Research Scope}

Future research can be done on the corporate, public sector or semi government organizations and can be compared with the findings of this research. Also a study can be conducted for comparison among services and manufacturing sector as well.

\section{Conclusion}

We conclude that Views component of office environment have impact on the efficiency and performance level of the office employees, it affects the productivity of the employees. If Views are favorable then office employees perform much better.

\section{References}

[1]. Yakubu Aminu Dodo, Mohd Zin Kandar, Muhammad Babale Girei , Ahmed Yahaya Abdul and Jallaludeen Mu'azu,“ Comparative Analysis of Effect of Psychological Factors on Visual Comfort in a Green and Conventional Office Building" ,2012 2nd International Conference on Biotechnology and Environment Management, IPCBEE vol.42 (2012) (C) (2012) IACSIT Press, Singapore

[2]. Aydin Ozdemir, "The effect of window views' openness and naturalness on the perception of rooms' spaciousness and brightness: A visual preference study" Scientific Research and Essays Vol. 5(16), pp. 2275-2287, 2010

[3]. Carlos E. Ochoa, Myriam B.C. Aries, Evert J. van Loenen and Jan L.M. Hensen, "Considerations on design optimization criteria for windows providing low energy consumption and high visual comfort", Applied Energy,vol.95,238-245.2012.

[4]. Seong-Hyun Park " Randomized clinical trials evaluating therapeutic influences of ornamental indoor plants in hospital rooms on health outcomes of patients recovering from surgery", 2006, Doctor of Philosophy, Kansas State University, Manhattan,

[5]. Heschong Mahone Group, Inc. Lisa Heschong, ProjectDirector,FairOaks,California,2003,"Windows and Offices: A Study of Office Worker Performance and the Indoor Environment",P-63.

[6]. Roger S. Ulrich, "Health Benefits of Gardens in Hospitals",Paper for conference, Plants for People ,International Exhibition Floriade 2002 